\title{
IMPLEMENTASI PENEGAKKAN UU PERS TERHADAP DELIK PERS DAN KEKERASAN JURNALIS DI TAHUN 2020
}

\author{
Andi Setyawan ${ }^{1}$, Fajar Muharam ${ }^{2}$, Jaka Atmaja ${ }^{3}$, Chepi Nurdiansyah ${ }^{4}$ \\ Universitas Bina Sarana Informatika, philosophyofawan@yahoo.com ${ }^{1}$, \\ Universitas Bina Sarana Informatika, fm.fajarmuharam@ gmail.com ${ }^{2}$, \\ Universitas Bina Sarana Informatika, jaka.jaj@bsi.ac.id ${ }^{3}$, \\ Universitas Bina Sarana Informatika, chepipunya@gmail.com ${ }^{4}$,
}

\begin{abstract}
ABSTRAK
Pers di negara berkembang seperti Indonesia adalah wujud dari implementasi demokrasi. Perannya yang sangat vital sebagai penyalur informasi dan konfirmasi bagi masyarakat, serta pembentuk opini publik menjadikan pers sebagai pilar ke-4 penyangga suatu negara. Eksistensi pers tentunya membutuhkan dukungan yuridis, dan saat ini terimplementasi dalam UU No 40 Tahun 1999 tentang Pers. Dengan adanya UU ini pers memiliki payung hukum serta batasan dalam menjalankan perannya sebagai kontrol sosial di masyarakat. Namun bukan tanpa celah, implementasi UU Pers juga menemui banyak kendala yang dirasa merugikan bagi pers itu sendiri. Kendala tersebut terkait tidak adanya delik pidana dalam UU Pers yang diatur dalam KUHP, karena UU Pers dianggap bukan lex specialist dari KUHP. Hal ini berdampak pada delik pers banyak yang tidak bisa diselesaikan dengan UU Pers melainkan harus melalui KUHP. Tulisan ini membahas tentang delik pers dan kekerasan jurnalis di tahun 2020 akibat paradok implementasi UU Pers ini. Hasilnya masih terdapat jurnalis yang mendapatkan vonis hukuman oleh pengadilan dan meningkatnya kekerasan tehadap jurnalis yang dilakukan oleh oknum masyarakat maupun aparat keamanan.
\end{abstract}

Kata kunci: pers, delik pers, UU Pers

\section{ABSTRACT}

Press in developing countries such as Indonesia is a manifestation of the implementation of democracy. Its vital role as a distributor of information and confirmation for the public, as well as the shaper of public opinion makes the press as the 4th pillar of a country's buffer. The existence of the press certainly requires juridical support, and is currently implemented in Law No. 40 of 1999 on the Press. With this Law, the press has a legal umbrella and restrictions in carrying out its role as social control in society. But not without loopholes, the implementation of the Press Law also encountered many obstacles that were perceived to be detrimental to the press itself. The constraints are related to the absence of criminal deliberation in the Press Law regulated in the Criminal Code because the Press Law is considered not a lex specialist of the Criminal Code. This has an impact on many press deliberations that cannot be solved by the Press Law but rather through the Criminal Code. This paper discusses the deliberations of the press and the violence of journalists in 2020 due to the paradok of this Press Law. As a result there are still journalists who get sentences by the courts and the increasing violence against journalists carried out by the public as well as the security forces.

Keywords: press, press deliberation, Law Of the 


\section{PENDAHULUAN}

Pers bagi sebuah negara memiliki fungsi dan peran yang cukup vital dan signifikan. Karena pada hakikatnya pers adalah alat untuk berkomunikasi dan berkonfirmasi dalam upaya penyebarluasan informasi. Bagi negara berkembang seperti Indonesia peran pers sangat dibutuhkan untuk memperlihatkan hasil-hasil pembangunan disegala aspek yang dilakukan pemerintah kepada masyarakat. Sehingga pada akhirnya juga mengajak masyarakat untuk ikut berperan serta dalam proses pembangunan.

Begitu besarnya peran pers bagi suatu negara sehingga membuat pers mempunyai pengaruh yang kuat dalam upaya pembentukan opini di masyarakat. Hal ini karena pers lewat media cetak maupun elektronik, mampu menjangkau masyarakat secara luas dan cepat tanpa batasan jarak dan waktu.

Sejarah pers di Indonesia merupakan perjalan panjang. Dimulai dari kelahiran UU Pers No 11 Tahun 1966 mengenai ketentuan-ketentuan pokok pers yang disempurnakan menjadi UU No 4 tahun 1967 lalu diubah menjadi UU No 21 Tahun 1982. Dan pada akhirnya pasca reformasi lahir UU baru yang memfasilitasi kebebasan pers yaitu UU No 40 tahun 1999 tentang Pers (Wina Armada Sukardi, 2007).

Ironisnya, undang-undang yang di gadang-gadang mampu memfasilitasi para pekerja jurnalistik dari aksi-aksi kriminalitas, nyatanya masih banyak benturan dalam pengimplementasiannya. Salah satunya adalah dalam banyak delik pers para penegak hukum menggunakan Kitab Undang Undang Hukum Pidana atau yang biasa disebut KUHP dibanding menggunakan UU Pers. Hal ini menyebabkan banyak kasus-kasus pelaporan pers oleh oknum yang menjadi objek berita dengan alasan pencemaran nama baik. Dan pada ranah ini delik

pidananya jelas akan menggunakan KUHP.

Jika kita mau menelaah UU Pers lebih jauh. Maka didalamnya hanya diatur 3 delik pers yaitu: delik atas asas praduga tak bersalah, delik norma susila, dan delik norma agama. Ironisnya, delik atas pencemaran nama baik ataupun penghinaan tidak diatur didalamya. Dan fenomena ini menimbulkan perdebatan di antara 2 kalangan. Pertama bagi kalangan pers UU ini sudah dapat dianggap sebagai lex specialist (aturan khusus) sebab pada dasarnya UU ini hanya mengatur dan meyelesaikan masalah yang berdampak akibat fungsi dan peran pers (Panjaitan, 2004). Berbeda dari kalangan Pers, Nono Anwar Makarim (ahli hukum) menilai UU Pers belum dapat disamakan dengan lex specialist disebabkan UU pers belum memenuhi syarat formal ataupun syarat material mengenai aspek-aspek hukum khusus. Hal ini disebabkan karena masih banyak kasus pidana terkait pers yang belum masuk didalamnya (Tjipta, 2005).

Karena paradox ini, di tahun 2020 pers mengalami pelonjakan kriminalitas terkait dengan penangkapan jurnalis. Ini termaksud juga dengan bagaimana jurnalis melakukan peliputan demonstrasi kemudian ditangkap oleh oknum apparat. Seperti dikatakan Ade dalam Focus Group Disscussion dengan tema Pandemi Covid-19: Pers antara kebebasan dan Keselamatan Jurnalis Dalam Krisis, Kamis (21/1/2021). Berdasarkan sumber dari LBH Pers (Ade Wahyudin), terdapat 10 jenis kekerasan yang dialami oleh pers selama tahun 2020 dengan jumlah kasus yang berbeda (Felldy, 2020):

1. Intimidasi atau kekerasan verbal sebanyak 51 kasus;

2. Penganiayaan sebanyak 24 kasus;

3. Pengrusakan atau perampasan sebanyak 23 kasus;

4. Penghapusan atau pemaksaan sebanyak 22 kasus;

5. Penangkapan sebanyak 19 kasus;

6. Penghalangan kerja sebanyak 14 kasus; Serangan digital sebanyak 12 kasus;

7. Ancaman sebanyak 12 kasus;

8. Kriminalisasi sebanyak 10 kasus; 
9. Gugatan perdata sebanyak 1 kasus.

Berdasarkan fenomena tersebut maka penulis tertarik untuk menganalisa delik pers serta kekerasan yang dialami jurnalis selama tahun 2020 serta hubungannya dengan paradoks pelaksanaan UU No 40 tahun 1999 tentang pers.

\section{Metode Penelitian}

\subsection{Pendekatan Dan Jenis Penelitian}

Pendekatan yang digunakan dalam penelitian ini adalah kualitatif. Pendekatan kualitatif dilakukan dengan menggunakan metode dokumentasi literatur dan informasi berita.

\subsection{Fokus Penelitian}

Fokus dalam penelitian ini adalah menganalisis delik pidana pada pers selama tahun 2020.

\subsection{Sumber Data}

Sumber data didapatkan melalui reportase media online dan press release Lembaga atau perusahaan media.

\subsection{Teknik Pengumpulan Data}

Teknik pengumpulan data yang digunakan dalam penelitian ini adalah dokumentasi terhadap berita yang ditayangkan oleh media online dan press release lembaga selama tahun 2020.

\subsection{Teknik Analisis Data}

Analisa data dilakukan untuk menemukan makna dari setiap data yang terkumpul. Kemudian setelah seluruh data terkumpul maka selanjutnya dipilah-pilah, dihubungkan, dan dibandingkan antara satu dengan yang lain. Dengan menggunakan proses berfikir rasional, analitik, kritik, dan logis, dicari persamaan dan perbedaannya. Hasil yang diperoleh dapat ditarik menjadi sebuah kesimpulan.

\section{Pembahasan}

Pers menurut Edmund Burke diartikan sebagai "the fourth Estate" atau dalam pengertian lain sebagai pilar ke-empat dengan fungsi sebagai watchdog. Pilar ke satu hingga ke empat yaitu Lembaga eksekutif, legislatif, dan yudikatif, berikutnya pilar ke empat yaitu pers atau media (Nair, 2009). Ke empat Lembaga tersebut ditambah masyarakat memiliki hubungan yang erat dalam upaya membangun bangsa. Didalam media terdapat sistem media yang dinaungi beberapa pihak-pihak terkait seperti:

1. Wartawan (pekerja media);

2. Pengusaha (pemilik media);

3. Masyarakat (audiens);

4. Pemerintah (regulator).

Dan jika dilihat dari kepentingannya, maka peran media akan diperebutkan oleh 2 kelompok besar yaitu: pertama adalah negara sebagai kekuatan politik, dan pengusaha sebagai kekuatan ekonomi. Media pada dasarnya merupakan organisasi yang memanfaatkan "communication technology" ataupun "information technology" hal ini digunakan untuk menyampaikan informasi-informasi kepada masyarakat agar masyarakat mendapatkan informasi secara langsung dari sumber terpercaya (Rogers, 1986). Seiring dengan berkembanganya teknologi, urgensi media semakin meningkat, dan hal inilah yang harus diselaraskan oleh pers.

Dinamika yang dialami media yang pada akhirnya mengaitkan jurnalis dengan maasyarakat, serta negara dengan pihak lainnya, adalah hubungan konstruktivis yang mengaitkan struktur dan agensi. Penguasa yang cenderung otoritatif akan membentuk media sebagai alat untuk memenuhi hegemoni politik. Sebaliknya, dalam ranah kapitalisme, pers akan dijadikan alat produksi bagi ekonomi untuk memenangkan pemilik modal (Mufid, 2005).

Secara rasional, pers memiliki peran yang cukup signifikan dalam pembentukkan opini, sikap, pola pikir, dan yang utama prilaku masyarakat. Oleh karena itu, dibutuhkan suatu regulasi untuk mengatur media agar sejalan dengan kebutuhan dan kepentingan nasional. Peraturan atau regulasi ini harus ditaati oleh pers dalam menjalankan tugas dan fungsinya. Dalam pengimplementasiannya, regulasi 
pers dapat berasal dari 2 sumber (Akil, 2012):

1. Peraturan yang dibuat dan ditetapkan oleh pemerintah, dalam hal ini tertuang dalam UU Pers;

2. Maupun keputusan atau kebijakan organisasi yang menaungi profesi pers, dalam hal ini dapat berbentuk Kode Etik Jurnalistik.

Denis Mc Quail menjabarkan pentingnya fungsi media (pers) sebagai berikut:

1. Media membuka lapangan pekerjaan, memungkinkan terjadinya perputaran barang dan jasa. Dalam artian ini, bahwa media menghidupkan industri lainnya. Serta menghubungkan industri lainnya dengan masyarakat.

2. Media dijadikan sebagai alat inovasi, menejemen, kontrol, serta pada akhirnya adalah sumber kekuatan di dalam sosial masyarakat dan ini dapat dimanfaatkan untuk kemaslahatan Bersama.

3. Media sebagai wadah untuk mengabadikan peristiwa peristiwa kehidupan di lingkup masyarakat, baik yang sifatnya regional, nasional, bilateral, maupun multi nasional.

4. Media akan memfasilitasi budaya untuk berkembang. Hal ini tidak hanya pengertian budaya dalam bentuk seni maupun simbol-simbol budaya, melainkan upaya pelestarian mode, gaya hidup, ataupun norma serta nilai yang berkembang dalam masyarakat.

5. Media dijadikan alat bagi masyarakat untuk melihat realitas sosial dalam bentuk nilai-nilai yang sifatnya normatif dalam wujud popular seperti berita dan hiburan.

Begitu pentingnya peran pers (media) bagi kehidupan berbangsa dan bernegara untuk membuat masyarakat melek terhadap informasi. Oleh karena itu, sudah sepatutnya pers didukung serta difasilitasi dalam melakukan tugasnya. Walaupun tetap dalam pengawasan Lembaga atau kelompok etik yang menaunginya.

1. Undang-Undang Pers Nomor 40 Tahun 1999

Peraturan yang mengatur jurnalis di Indonesia adalah UU No 40 tahun 1999 mengenai pers. Didalamnya disebutkan "Pers adalah lembaga sosial dan wahana komunikasi massa yang melaksanakan kegiatan jurnalistik meliputi mencari, memperoleh, memiliki, menyimpan, mengolah, dan menyampaikan informasi baik dalam bentuk tulisan, suara, gambar, suara dan gambar, serta data dan grafik maupun dalam bentuk lainnya dengan menggunakan media cetak, media elektronik, dan segala jenis saluran yang tersedia”. Dalam pengertian yang lebih umum bahwa pers pada hakikatnya adalah sebuah industri media yang terdiri atas industri media cetak maupun elektronik. Didalam amanat UU Pers pasal 3 ayat (1)(2) pers nasional memiliki fungsi sebagai media informasi, hiburan, pendidikan, serta kontrol sosial. Selain itu, pers nasional juga dapat berfungsi sebagai Lembaga ekonomi (Undang Undang No. 40 Tahun 1999, n.d.).

2. Hak Jawab, Hak Tolak, dan Hak Koreksi di Dunia Pers

Dalam UU No 40 Tahun 1999 mengenai pers, pada dasarnya ada 3 hak yang diharapkan berjalan secara bersamaan dan wajib dijalankan oleh perusahaan pers dan juga jurnalis itu sendiri, bahkan bagi masyarakat sekalipun. Hal ini terimplementasi dalam pasal 1 angka 10, 11, dan $12 \mathrm{UU}$ pers yaitu: hak tolak, hak jawab, dan hak koreksi.

Hak tolak diartikan sebagai hak bagi wartawan atas profesinya untuk menolak serta mengungkapkan identitas maupun nama dari hal yang harus 
dirahasiakan (sumber berita). Selanjutnya adalah hak jawab, hak ini melekat pada diri masyarakat (seseorang maupun kelompok masyarakat) untuk memberikan jawaban, tanggapan, maupun hal yang sifatnya sanggahan atas berita yang merugikan nama baiknya. Dan yang terakhir adalah hak koreksi adalah hak untuk membetulkan atas kekeliruan informasi yang diberitakan oleh pihak pers, hal ini baik menyangkut tentang orang lain maupun diri sendiri.

Pelaksanaan dari hak-hak ini, di jelaskan pada pasal 2 ayat (2) dan (3) UU Pers, mengenai pers yang memiliki kewajiban untuk melayani hak jawab serta hak tolak. Hak tolak ini dikuatkan pada pasal 4 ayat (4) dengan bunyi, dalam mempertanggungjawabkan pemberitaan di depan publik, maka wartawan memiliki hak untuk menolak.

Lanjutan terkait implementasi hak tolak dijabarkan dalam pasa 4 ayat (4) yang memaparkan bahwa tujuan hakiki dari hak tolak adalah agar pencari berita (wartawan) dapat melindungi sumber informasinya. Yaitu dengan cara menolak untuk memberikan identitas dari sumber informasinya. Hak ini bisa digunakan dalam beberapa kepentingan diantaranya saat wartawan dimintai keterangan oleh pejabat penyidik dan atau diminta menjadi saksi dalam pengadilan. Walau, hak ini tidak bisa berdiri tegak jika menyangkut keselamatan negara maupun ketertiban umum yang diputuskan oleh pengadilan.

Perihal berikutnya adalah kewajiban untuk mengoreksi. Dijelaskan lebih lanjut dalam UU Pers pasal 1 angka 13 bahwa ada kewajiban yang melekat bagi Pers untuk melakukan ralat maupun koreksi atas suatu informasi, gambar, opini, fakta maupun data yang dinilai tidak benar adanya dan telah diterbitkan oleh perusahaan pers yang bersangkutan. Dalam hal jika ada perusahaan pers yang terkesan tidak memperdulikan atas suatu hak jawab. Maka perusahaan tersebut dapat dikenakan denda pidana dengan denda paling banyak Rp. 500.000.000;. Hal ini dijabarkan pada pasal 18 ayat (2) UU Pers.

\section{Kemerdekaan Pers}

Pada dasarnya kemerdekaan Pers tertuang dan dijamin dalam pasal 4 Ayat (1) UU Pers yang juga termasuk dalam hak asasi warga negara Indonesia. Dalam pengertian bahwa pers adalah bagian dari hak asasi warga negara berarti pers merdeka dari tindakan pelarangan, pencegahan, serta penekanan. Hal ini agar hak masyarakat untuk mendapatkan informasi dapat dijamin sepenuhnya oleh Undang-Undang. Wujud kemerdekaan pers harus dimbangi dengan penegakkan hukum yang diatur oleh pengadilan, serta tanggung jawab profesi yang diamanahkan di dalam kode etik jurnalistik.

Kemerdekaan pers ini juga akan berimplikasi pada orang atau kelompok maupun lembaga yang secara terangterangan menghambat atau sengaja menghalangi pelaksaaan kemerdekaan pers seperti apa yang diamanatkan pada UU Pers pasal 4 ayat (2)(4). Maka, akan ada implikasi pidana denda paling banyak Rp 500.000.000; dan penjara paling lama 2 tahun. Aturan pidana ini dimuat pada UU Pers pasal 18 ayat (1).

Sebenarnya jika kita mau telaah lagi kebelakang, bahwa kemerdekaan pers dalam wujud yang bertanggung jawab adalah implementasi dari suatu negara demokrasi. Dimana kepentingan rakyat adalah yang utama dan patut untuk diperjuangkan. Dan jika kita Tarik pada ranah ke Indonesiaan maka kemerdekaan pers ini sudah tertuang pada pasal 28 UUD 1945 yang menjamin kemerdekaan untuk berserikat dan berkumpul untuk mengeluarkan pikiran baik lisan maupun tulisan, dan ini diatur dalam undangundang (Hikmat, 2005).

\section{Delik Pers \& Kasus Kekerasan Pada Jurnalis Selama Tahun 2020}

Jika kita membicarakan kasus kriminalitas yang dialami oleh jurnalis selama tahun 2020. Kita dapat melihat transformasi tindakan dari upaya pelaporan delik pers menjadi upaya kekerasan represif (sepihak) terhadap jurnalis. Tentunya hal ini tanpa melalui prosedur-prosedur hukum yang telah ditentukan. Selain masih ada pelaporan delik pers yang kemudian diproses dipengadilan hingga oknum jurnalis 
ditetapkan sebagai tersangka dan mendapatkan hukuman. Tak sedikit juga upaya-upaya main hakim sendiri terhadap jurnalis karena dinilai pemberitaan jurnalis tersebut berlebihan dan cenderung mendeskreditkan satu pihak atau golongan.

Ditahun 2020 dikonfirmasi terdapat 10 jurnalis yang dikriminalisasi dan dua orang divonis penjara oleh pengadilan. Yang pertama oleh pengadilan negeri buton dan yang kedua pengadilan negeri Kota Baru. Dari 10 kasus ini seluruhnya mengaitkan dengan UU ITE dengan pasa 27 ayat 3 mengenai ujaran kebencian (Makdori, 2021).

Contoh pertama kasus pemidanaan pers adalah kasus wartawan Diananta Putra Sumedi dari Banjarhits.com. masalah ini diawali dari tulisannya

Banjarhits.id/Kumparan.com berdasarkan data dan fakta dari beberapa narasumber suku Dayak yaitu Sukirman, Riwinto, dan Bujino dengan tajuk "Tanah Dirampas Jhonlin, Dayak Mengadu ke Polda Kalsel" diterbitkan pada 8 November 2019 pukul 19.00 WITA.

Masalah ini pada awalnya sudah dilaporkan ke Dewan Pers untuk ditindak. Namun, meski Dewan Pers sudah memprosesnya Polisi tetap memproses masalah ini hingga pada akhirnya masalah ini berujung ke pengadilan. Dan hasilnya Diananti mendapatkan vonis bersalah atas penyebaran informasi sehingga megakibatkan kebencian atas kelompok atau individu tertentu yang menyangkut aspek agama, suku, dan ras. Sehingga Diananta dikenakan pasal 28 UU ITE. Disini terlihat bahwa hakim tidak mengindahkan UU Pers untuk dijadikan lex specialist sebagai peraturan yang seharusnya digunakan untuk menyelesaikan sengketa suatu pemberitaan (Bayhaqi, 2020).

Dari contoh kasus tersebut maka ini cukup menjadi perhatian besar terhadap kebebasan pers di Indonesia. Dengan adanya kasus tersebut maka bisa jadi kedepannya akan digunakan oleh siapa saja untuk melakukan intimidasi, bahkan mempidanakan jurnalis jika merasa dirinya diganggu oleh pers. Dengan ini maka tidak akan bisa terwujud fungsi pengawasan sosial oleh pers.

Berdasarkan pemaparan dari Direktur Eksekutif LBH Pers Ade Wahyudin, hingga Desember 2020 terdapat 117 kasus kekerasna terhadap jurnalis, dan ini naik $32 \%$ dari tahun 2019. Selama 2020 juga mencetak angka tertinggi penangkapan jurnalis oleh oknum apparat yaitu sejumlah 19 kasus. Salah satu pihak pers yang paling rentan terkena penangkapan oleh apparat adalah pers mahasiswa. Mengapa demikian, karena pers mahasiswa tidak dilindungi badan hukum, berbeda dengan kalangan pers professional yang berada di bawah naungan lembaga pers (Azria, 2021).

Divisi advokasi AJI mendokumentasikan daerah dengan tindak kriminalitas terhadap pers tertinggi yaitu Jakarta dengan 17 kasus, Malang 15 kasus, Surabaya 7 kasus, Samarinda 5 kasus, palu 4 kasus, Gorontalo 4 kasus, lampung 4 kasus, sisanya daerah lainnya. Ada kasus kriminalitas besar yang dialami jurnalis terkait kekerasan, yaitu 56 jurnalis ketika meliput demonstrasi menolak UU Cipta Kerja dari tanggal 7 hingga 21 Oktober 2020 di beberapa daerah. Yang menjadi perhatian, semua pelaku kekerasan terhadap jurnalis dilakukan oleh aparat penegak hukum. Untuk kasus di Jakarta 6 jurnalis ditahan di Polda Metro Jaya, walau dua hari kemudian mereka dibebaskan. Terdapat juga kasus di ranah digital yang dialami jurnalis Tempo yaitu peretasan terhadap akun media sosial, email, serta aplikasi pengiriman pesan instan di HP-nya ketika jurnalis Tempo tersebut selesai menulis laporan bansos pada 24 Desember 2020 (Satriadi, 2020). Masalah doxing atau pembongkaran dan pelacakan identitas juga terjadi di tahun 2020. Jurnalis Liputan6.com mengalami doxing atas liputannya yang diterbitkan pada tanggal 10 September 2020. Pelaku doxing menyebarkan data jurnalis ke beberapa akun media sosial tanpa izin dari jurnalis, sehingga terkesan mendeskreditkan narasumber. Doxing juga dialami 
wartawan Tempo.co yaitu Zainal ishaq serta Ika Ningtyas atas beritanya terkait klaim M.Indro Cahyono yang merupakan dokter hewan terkait Covid-19. Wartawan Detik.com juga tak luput dari serangan doxing setelah menulis berita terkait jadwal kunjungan presiden membuka mall dikawasan Bekasi padahal kasus Covid-19 sedang tinggi-tingginya saat itu.

Dalam masalah yang lain, AJI melihat dan mencermati peraturan Mahkamah Agung No 5 tahun 2020 terkait peraturan dan protokol persidangan dan keamanan dalam lingkungan pengadilan yang diresmikan pada 27 November 2020. Dalam peraturan tersebut dijelaskan mengenai prosedur pengambilan foto, rekaman audio visual, serta rekaman audio harus terlebih dahulu mendapatkan izin ketua majelis hakim. Mirisnya terdapat ancaman pemidanaan bagi mereka yang melanggar. Dalam hal ini jelas terdapat pembatasan hak insan pers dalam mendapatkan suatu informasi dalam UU No 40 tahun 1999 mengenai pers.

Jika kita telaah lebih lanjut, ada 3 kriteria umum. Mengenai delik pers menurut Van Hattum (Sadono, 1993):

1. Delik pers harus dilakukan atas barang-barang cetakan;

2. Hal yang dipidanakan berwujud pernyataan perasaan atau pikiran.

3. Berdasarkan rumusan delik, publikasi adalah syarat untuk dapat menciptakan kejahatan. Jika dan hanya jika kejahatan tersebut dinilai berdasarkan tulisan.

Atas delik baru dinilai sesuai dengan syarat atas delik pers, jika kejahatan mengandung pernyataan perasaan atau pikiran dan diimplementasikan dalam wujud cetakan dan dipublikasikan.

Lebih lanjut Seno Adji membatasi delik pers yang dapat dikenakan pidana adalah untuk menghindari penyalahgunaan atas kemerdekaan pers. Dan ini dijabarkan dalam beberapa kerangka hukum:

1. Delik atas ketertiban umum serta keamanan negara: pasal
112 dan 113 KUHP dan pasal 154 , pasal 155 , pasal 156 , pasal 157 dan pasal 207.

2. Delik atas penghinaan: pasal 310 dan 315 KUHP.

3. Delik atas agama: pasal 156 dan pasal 156a KUHP.

4. Delik atas kabar yang tidak benar: Undang-undang Nomor 1 Tahun 1946 pasal 14 dan pasal 15.

Pembatasan ini jadi menarik ketika UU Pers tidak mengatur persyaratan seperti poin-poin di atas sebagai syarat penerapan pidana khusus. Seperti kita ketahui bahwa didalam UU Pers tidak termuat pengklasifikasian pelanggaran serta kejahatan. Oleh karena itu, sebagai rujukan utama dari pelaksanaan hukum di Indonesia maka KUHP mengikat peraturan-peraturan pidana lainnya, tidak terkecuali UU Pers.

Sebagai bentuk dari aturan khusus UU Pers sewajarnya harus memenuhi prasyarat dari delik KUHP terkait pelanggaran dan kejahatan. Karena KUHP adalah rujukan utama seluruh hukum maka praktek legislatifnya harus memakai pola pemidanaan berdasar KUHP sebagai acuan dalam penerbitan aturan perundangan pidana berikutnya.

Yang jadi menarik untuk diamati bahwa UU Pers pada dasarnya hanya berisi kewajiban dan hak dari pers. Hal ini menjadi rancu, karena jika pers melakukan tindak pidana umum yang sebelumnya sudah tertera dalam KUHP. Maka, penegak hukum yang memproses kasus tersebut tidak bisa menggunakan UU Pers sebagai acuan delik pidana, melainkan harus merujuk pada KUHP. Hal ini dikarenakan UU Pers tidak menjadi 
bagian dari kekhususan (lex specialist) dari KUHP.

Terkait dengan transformasi pelaporan delik pers menjadi Tindakan represif yaitu kekerasan terhadap jurnalis. Seharusnya pihak yang merasa dirugikan atas pemberitaan seorang jurnalis dapat melakukan hak jawab seperti diatur dalam UU Pers No 40 tahun 1999. Bukannya malah melakukan Tindakan pribadi yang justru berbuntut pada kerugian yang diterima jurnalis seperti membuka data pribadi jurnalis beserta keluarganya maupun Tindakantindakan represif lainnya. Hal ini selain bisa membunuh karakter jurnalis, juga bisa merugikan secara meteril dan immaterial.

\section{Peran Masyarakat dalam Mengawasi Pers}

Masyarakat secara umum diharapkan mampu menjadi fungsi pengawas pers. Hal ini di amanatkan dalam pasal 17 ayat (1)(2) UU Pers yang menjelaskan bahwa masyarakat dapat melakukan upaya kegiatan agar mengembangkan kemerdekaan pers serta menjamin hal untuk mendapatkan informasi ataupun berita yang diperlukan. Kegiatan-kegiatan ini dapat berupa:

1. Memantau serta melaporkan analisis mengenai adanya indikasi pelanggaran hukum serta kesalahan teknis dalam kegiatan pemberitaan yang dilakukan oleh pers.

2. Mengusulkan serta menyarankan kepada Dewan Pers terkait menjaga serta meningkatkan kualitas pers nasional. Dalam hal adanya dugaan pelanggaran kode etik yang mungkin dilakukan oleh oknum pers, maka dalam koridor ini peran dan tanggung jawab Dewan Pers untuk menyelesaikannya.

\section{Analisa}

Pada hakikatnya wujud kemerdekaan pers tidak mungkin -tidak terbatas. UU Pers juga memberikan pengertian terkait kemerdekaan pers sebagai wujud pelaksanaan hak asasi manusia. Hal ini diwujudkan atas dasar kepentingan masyarakat. Bahwa tindakan pencegahan, pelarangan, dan penekanan kepada pers akan menghambat distribusi informasi kepada masyarakat. Kemerdekaan pers disini adalah suatu kebebasan yang diimbangi dengan tegaknya hukum diberlakukan, serta adanya pengawasan ketat dari organisasi profesi agar pers tetap menjalankan tugas dalam koridor yang telah ditetapkan.

Tidak dapat kita pungkiri bahwa maraknya tindak pidana atau delik pers disebabkan karena berita yang dibuat oleh jurnalis terkesan berlebihan dan seakan keluar dari etika jurnalistik. Walau dalam UU Pers telah ada aturan dan penjelasan bahwa peran pers adalah untuk mengembangkan pendapat masyarakat umum, dengan menerbitkan berita yang benar, tepat, dan akurat. Disinilah seringkali bagi oknum atau kelompok yang menjadi sumber berita dirasa tidak nyaman karena berita yang ditayangkan terlalu detil menjelaskan oknum tersebut. Hal ini dilain sisi masih dapat dikatakan wajar, karena manusia secara pribadi butuh privasi dan keamanan diri.

Dari sisi pers membuat berita yang tidak terkesan menghakimi atau menyimpulkan terkait kesalahan seseorang. Utamanya untuk masalahmasalah yang sedang dalam proses peradilan adalah hal yang harus dijunjung tinggi bagi para pencari berita agar semua pihak mendapat porsi kebenaran berita yang sama tanpa ada yang merasa dirugikan.

Tanggung jawab pers dalam suatu tatanan negara adalah berupaya untuk menyajikan suatu kegiatan politik dengan seutuhnya. Memang tidak dapat dipungkiri bahwa tanggung jawab pers akan bersinggungan dengan kekuasaan irresponsible system of power, atau kekuasaan yang tidak bertanggung jawab. Dimana pada saat itu tanpa disadari keluar dari struktur kekuasaan yang tidak 
pernah diupayakan dikontrol (Dhakidae, 1997).

\section{Landasan Teori}

Dalam penelitian ini, Penulis menggunakan beberapa teori untuk menkaji permasalahan ini, antara lain :

\section{Teori Kesengajaan.}

Berhubungan dengan keadaan batin orang yang berbuat dengan sengaja yang berisi menghendaki dan mengetahui itu, dalam hukum pidana dikenal 2 (dua) teori sebagaai berikut :

a) Teori Kehendak (wilstheorie)

Teori ini dikemukakan oleh Von Hippel dalam bukunya Die Grenze Vorsatz und Fahrlassigkeit terbitan tahun 1903, menurutnya kesengajaan adalah kehendak membuat suatu tindakan dan kehendak menimbulkan suatu akibat dari tindakan itu. Akibat dikehendaki apabila itu yang menjadi maksud dari tindakan itu. Menurut aliran determinisme, manusia tidak mempunyai kehendak bebas, manusia melakukan suatu perbuatan didorong oleh beberapa hal, baik yang

berasal dari sanubari maupun dari luar dirinya.15 Aliran Indeterminisme muncul sebagai reaksi atas mazhab determinisme, menurut aliran ini walaupun untuk melakukan sesuatu perbuatan dipengaruhi oleh bakat dan milieu, manusia dapat menentukan kehendaknya secara bebas. Namun aliran determinisme tidak dapat diterapkan dalam hukum pidana karena akan menimbulkan kesulitan dalam hal pertanggungjawaban. 16

b) Teori Membayangkan (voortstellingstheorie)

Teori ini dikemukakan oleh Frank dalam bukunya Festscrift Gieszen tahun 1907, teori ini mengemukakan bahwa manusia tidak mungkin dapat menghendaki suatu akibat, manusia hanya dapat mengingini, mengharapkan atau membayangkan (voorstellen) kemungkinan adanya suatu akibat. Adalah sengaja apabila suatu akibat yang ditimbulkan dari suatu tindakan dibayangkan sebagai maksud dari tindakan itu.

\section{Teori Kesadaran Hukum dan ketaatan Hukum.}

Ewick dan Silbey dalam Achmad Ali mengemukakan bahwa kesadaran hukum terbentuk dalam tindakan dan karenanya merupakan persoalan praktik untuk dikaji. Dengan kata lain, kesadaran hukum adalah persoalan hukum sebagai perilaku, dan bukan hukum sebagai aturan, norma, atau asas. Oleh karena itu, dalam hal ini antara kesadaran hukum dan ketaatan hukum erat kaitannya satu sama lain, dan nantinya juga akan berpengaruh terhadap efektivitas hukum.

Mengenai ketaatan hukum, H. C. Kelman mengemukakan bahwa kualitas ketaatan hukum dapat dibedakan menjadi beberapa bagian, yaitu sebagai berikut :

1). Ketaatan yang bersifat compliance, yaitu jika seseorang menaati suatu aturan, hanya karena ia taku terkena sanksi. Kelemahan ketaatan jenis ini, karena ia membutuhkan pengawasan terus-menerus.

2). Ketaatan yang bersifat identification, yaitu jika seseorang menaati semua aturan, hanya karena takut hubungan baiknya dengan pihak lain menjadi rusak.

3). Ketaatan yang bersifat internalization, yaitu jika seseorang menaati suatu aturan, benar-benar karena ia merasa bahwa aturan itu sesuai dengan nilai- nilai intrinsik yang dianutnya. memberikan banyak informasi dan menghimpun segala tingkatan kecerdasan.

\section{Teori Penegakan Hukum}

Untuk menganalisa mengenai penegakan hukum terhadap Pelanggaran Terhadap Asas Praduga tak bersalah oleh media Pers dalam anatomi kejahatan maka digunakan teori penegakan hukum. Secara konsepsional inti dari penegakan hukum menurut Soerjono Soekanto 
terletak pada kegiatan menyerasikan hubungan nilai-nilai yang terjabarkan di dalam kaidah kaidah yang mantap dan mengejawantahan serta sikap tindak sebagai rangkaian penjabaran nilai tahap akhir, untuk menciptakan, memelihara dan mempertahankan kedamaian pergaulan hidup.17.

\section{Teori pemidanaan}

Mengenai pengertian pemidanaan, Andi Hamzah dalam Tolib Setiady mengemukakan bahwa "pemidanaan disebut juga sebagai penjatuhan pidana atau pemberian pidana atau penghukuman. Kemudian beliau menegaskan kembali bahwa, pemberian pidana tersebut mempunyai dua arti yaitu dalam arti umum dan dalam arti konkret. Dalam arti umum, menyangkut pembentuk undang-undang ialah yang menetapkan stelsel sanksi hukum pidana (pemberian pidana in abstracto), sedangkan dalam arti konkret, ialah yang menyangkut berbagai badan atau jawatan yang kesemuanya mendukung dan melaksanakan stelsel sanksi hukum pidana itu.

\section{Kesimpulan}

Undang-Undang Pers No 40 Tahun 1999 pada dasarnya cukup menimbulkan paradoks. Disatu sisi Undang Undang ini ingin melindungin pers dan memberikan payung hukum yang jelas. Namun, dilain sisi Undangundang ini tidak memuat aspek-aspek delik pidana seperti yang diamanatkan dalam KUHP. Padahal, KUHP sebagai rujukan utama dari peraturan-peraturan yang berimplikasi pidana lainnya. Karena undang-undang pers tidak menjadi bagian dari KUHP (Lex specialist), maka UU Pers No 40 tahun 1999 tidak dapat dipakai di persidangan yang melibatkan anggota pers selaku pelaku dalam tindak pidana yang ada dan diatur di dalam KUHP.

Implikasi dari kondisi tersebut adalah semakin mudahnya oknum atau kelompok masyarakat yang mempidanakan pers atas dasar pencemaran nama baik. Dan dalam wujud yang lain, banyak tindak kekerasan yang dialami oleh jurnalis dari oknum masyarakat maupun apparat keamanan karena pers dinilai mendeskreditkan mereka atau melebihlebihkan suatu informasi dari keadaan yang sebenarnya. Oleh karena itu, jika UU Pers ingin memiliki posisi yang kuat untuk melindungi insan pers maka perlu adanya upaya untuk merevisi UU tersebut agar menjadi lex specialist dari KUHP.

\section{Daftar Pustaka:}

Akil. (2012). Ilmu Komunikasi: Konstruksi, Proses, dan Level Komunikasi Kontemporer. Makassar: Alaudin University Press.

Azria, Z. (2021). LBH Pers: Kekerasan Pada Jurnalis Pada 2020 naik $32 \%$. Retrieved from www.alinea.id

Bayhaqi, A. (2020). B AJI: 2020 Tahun Kelam Bagi Jurnalis Indonesia. Retrieved from www.merdeka.com Dhakidae, D. (1997). Negara \& Kecemburuannya pada Pers: Suatu Tinjauan Ideologis. Surabaya: Midas Surya Grafindo.

Felldy, U. (2020). Inilah Kekerasan yang Dialami Jurnalis Sepanjang 2020. Retrieved from www.nasional.sindonews.com

Hikmat, K. \& P. (2005). Kusumaningrat, Hikmat \& Purnama. 2005. Jurnalistik Teori \& Praktek. Jakarta.

Makdori, Y. (2021). LBH Pers: 10 Jurnalis Dikriminalisasi Sepanjang 2020, 2 Divonis Penjara. Retrieved from www.liputan6.com

Mufid. (2005). Komunikasi \& Regulasi Penyiaran. Jakarta: Prenada Media.

Nair, M. (2009). Journalism and Democracy (dalam The handbook of Journalisme Studies, Edited by Karin Wahl-Jorgensen and Thomas Hanitzsch). New York: Routledge.

Rogers. (1986). Communication Technology: The New Media in Society. New York: The Free Press.

Sadono, B. (1993). Penyelesaian Delik 
Pers Secara Politis. Jakarta: Sinar Harapan.

Satriadi, R. (2020). 2020, Tahun Kelam Bagi Jurnalis Indonesia. Retrieved from www.beritasatu.com

Tjipta, L. (2005). Pencemaran Nama Baik dan Kebebasan Pers : antara Indonesia dan Amerika. Jakarta: Penerbit Erwin-Rika Press.

Undang Undang No. 40 Tahun 1999. (n.d.).

Wina Armada Sukardi. (2007). Keutamaan di Balik Kontroversi Undang-Undang Pers. Jakarta: Dewan Pers.

Dewi Bunga, 2011, "Penegakan hukum Terhadap Prostitusi Cyber (Suatu Kajian Dalam Anatomi Kejahatan Transnasional)" (tesis). Denpasar: Universitas Udayana.

Leden Marpaung, 2005, Asas Teori Praktik Hukum Pidana, Sinar Grafika, Jakarta, hal 16.

\section{Biodata Penulis:}

1 Andi Setyawan, Lahir di Jakarta 24 Juni 1987. Merupakan mahasiswa Aktif Sekolah Pascasarjana Universitas SAHID Jakarta Angkatan 2019 jurusan Magister Ilmu Komunikasi. Aktif sebagai dosen dengan konsentrasi bidang komunikasi massa \& metode penelitian komunikasi.

${ }^{2}$ Fajar Muharam, lahir di Jakarta 15 Agustus 1988. Merupakan mahasiswa Aktif Sekolah Pascasarjana Universitas SAHID Jakarta Angkatan 2019 jurusan Magister Ilmu Komunikasi. Mengajar di program studi penyiaran, dan praktisi dibidang komunikasi.

3 Jaka Atmaja S,Ikom, M.M. Merupakan mahasiswa aktif Sekolah Pascasarjana USAHID Jakarta, angakatn 2019 jurusan Magister Ilmu
Komunikasi. Lahir di Jakarta 26 Februari 1984, aktif sebagai dosen di Fakultas Ilmu Komunikasi \& Bahasa UBSI dari tahun 2015-sekarang.

\section{${ }^{4}$.Chepi Nurdiansyah S.Ikom,} M.M. Merupakan mahasiswa aktif Sekolah Pascasarjana USAHID Jakarta, angakatn 2019 jurusan Magister Ilmu Komunikasi. Lahir di Jakarta, 28 Juli 1986. aktif sebagai dosen di Fakultas Ilmu Komunikasi \& Bahasa UBSI dari tahun 2015sekarang. 